several studies of forest damage in West Germany, is not so quick to rule out a role for sulphur dioxide. He emphasizes that "occult" precipitation - fog and mist can be much more acidic than rain and may yet play a part, perhaps in conjunction with other stress factors.

If there is still mystery over the mechanism of damage to trees, the mechanism of damage to fish in fresh water is rather better understood. It seems that elevated levels of inorganic aluminium may be a major cause of mortality. But the chemical changes that will occur in a body of water subjected to acid deposition within its catchment area are greatly affected by the nature of the soil and bedrock, as well as by the type of vegetation present. It is clear that coniferous trees, in particular, can efficiently filter out acids from the air and release these in solution at the next rainfall. The Forestry Commission in Britain is already investigating management practices that may reduce acid release into streams.

Because of the multitude of factors that affect acid depositions, the precise attribution of blame is difficult or impossible. Motor vehicles, for example, along with power stations may be (indirectly) a major source of ozone, through their emissions of nitrogen oxides. But the British contingent at Munich this week will doubtless be able to make much of new estimates published by the Department of Energy of the proportion of British-emitted sulphur dioxide that finds its way to other countries: 3.6 per cent to West Germany, 4.4 per cent to Norway and Sweden combined, while almost 30 per cent stays in Britain.

While the British Department of Energy harks on the quantitative uncertainties of acid deposition, the Nature Conservancy Council, which also last week published its views on the matter, takes a somewhat different line. It argues that acidification reduces species diversity in aquatic systems and that the only long-term solution to the problem is therefore to reduce emissions of sulphur and nitrogen oxides. And it is opposed to the policy of liming affected waters on the grounds that the practice will in the long term bring its own undesirable effects.

The British Government seems likely to find itself increasingly isolated over acid emissions. The government is commited to reply before the end of the current parliamentary session to the latest report of the Royal Commission on Environmental Pollution, which urged that the Central Electricity Generating Board should introduce emission abatement measures on a pilot basis. And the Select Committee on the Environment of the House of Commons is shortly to report on the results of its inquiry into "acid rain", which, it may be guessed, will not take a complacent view. It seems likely that political pressure will before long force some government concessions.

Tim Beardsley
Pesticides

\section{New chemicals under fire}

THE latest returns in a two-year survey of the British barn owl population suggest an even greater population decline than had been feared. Ten years ago there were some 4,500-9,000 pairs in England, Scotland and Wales and now, after 18 months of the "Barn Owl Survey" organized by the Hawk Trust, the indications are that the overall decline has been at least 10 per cent, with much greater reductions in many areas.

The only areas where there has been little decline are in Scotland, where the Forestry Commission's activities have provided some additional refuge for the dwindling population. The population estimates, however, are becoming increasingly inexact as the numbers involved get smaller.

The continued decline of the barn owl is thought, says Colin Shawyer of the Hawk Trust, to be a result of the use of new rodenticides by British farmers. Difenacoum and brodifacoum have been growing in popularity in the past few years, steadily replacing warfarin, which is known to be relatively non-toxic to species other than rodents. Brodifacoum is thought to be especially toxic to birds and for that reason has not been given full approval by the Ministry of Agriculture, Fisheries and Food under the Pesticides Safety Precautions Scheme.

Some of the evidence for the effects of the new pesticides comes from Malaysia. On some oil palm plantations, the combination of warfarin and the wild barn owls, encouraged by the provision of nestboxes on poles throughout the plantations, has effectively controlled severe rat infestations. But even on estates where there has been no evidence of warfarin resistance, the new pesticides have been tried. And, says the Hawk Trust, barn owl numbers declined so rapidly that the estate managers went back to the old methods.

In Britain, some farmers have reported

Victims both - a barn owl and prey. to the Hawk Trust that barn owls seemed to disappear from their farms soon after they started using the "second generation" rodent baits. And a veterinary surgeon reported that a barn owl thought to be dying from the effects of difenacoum poisoning was successfully treated by the vitamin $\mathrm{K}$ antidote to the pesticide.

Much of the evidence on pesticide toxicity is circumstantial, the Hawk Trust concedes. So the urgent need is for more research on the effects of the new chemicals on non-target species.

Charles Wenz

\section{Irreproducing ibis Tokyo}

EFFORTS to save Japan's Nipponia Nippon (the Japanese crested ibis or "toki") seem doomed to failure after a romance between two of the remaining birds - Kin (the female) and Midori (the male) — ended in a mid-mating season fight. As Kin is now, in human terms, around 80 years old, the chances of a successful mating next year are thought to be close to nil, although hormones are to be administered in the hope of keeping her in breeding condition.

The toki, a large white bird with a characteristic long downwardly curved black bill and a red face, was a common sight in wet paddy fields and ponds throughout Japan and parts of east Asia as recently as one hundred years ago. But a catastrophic decline in their numbers this century led to their being given special status in Japan in 1934. The war prevented any serious conservation measures, however, and by 1953 only 31 birds remained.

In 1966, special measures were begun but numbers continued to decline so, in 1981, the remaining five wild birds and one captive bird were removed to a breeding centre on the island of Sado - where in bygone days troublesome cadet branches of the imperial family were exiled so that their lines might disappear. Two birds died but hopes rose in 1983 when two of the remaining four birds paired. The female died, however, from a blocked fallopian tube shortly before she laid her eggs.

This year, the romance between $\mathrm{Kin}$ and Midori was followed closely but to no avail. As well as being in ripe old age, $\mathrm{Kin}$, having been reared in captivity, apparently did not take too well to Midori, who had led $a$ life in the wild until 1981.

The Sado Island Toki Centre is now to advance research on artificial insemination as fast as possible, but researchers doubt whether practical methods can be developed in time. Hopes for saving Nipponia Nippon from extinction now rest largely with the Chinese. In 1980, seven birds were found in China, raising the known numbers there to fourteen - the same as the number remaining in Japan. There have been occasional rumours of sightings in Korea and the southeastern Soviet Union, but none has been confirmed.

Alun Anderson 